\title{
The value of LYM-1 cells for examining vacuole formation and loss of cell viability induced by culture supernates of Helicobacter pylori
}

\author{
X. M. WANG, T. KOJIMA, K. SATOH, Y. TANIGUCHI, K. TOKUMARU, K. SAIFUKU, M. SEKI, \\ K. KIHIRA, K. IDO, J. Y. UCHIDA, C. OHMORI, T. TAKAOKA and K. KIMURA \\ Departments of Gastroenterology and Medical Zoology, Jichi Medical School and Utsunomiya East Hospital, \\ Japan
}

\begin{abstract}
Some strains of Helicobacter pylori are known to produce an extracellular cytotoxin that causes vacuolation in cultured mammalian cells. Screening for such strains makes use of HeLa cells which may not be sensitive enough to detect minimal changes. The aim of this study was to develop a more sensitive cell line. Vacuole formation was examined in HeLa cells, as well as four other cell lines established in this laboratory by ammonium chloride induction. Among five cell lines tested, LYM-1 cells were most sensitive for the detection of intracellular vacuolation with this agent. Loss of cell viability of LYM-1 and HeLa cells induced by $H$. pylori culture supernates was also examined: LYM-1 were more sensitive than HeLa cells. Cell death was not always accompanied by vacuole formation. This suggests that the mechanism whereby cell death occurs must be different from that for vacuole formation. LYM-1 cells may be useful when measuring vacuole formation and cell death of the cultured cells induced by culture supernates of clinical isolates of $\boldsymbol{H}$. pylori.
\end{abstract}

\section{Introduction}

Some strains of Helicobacter pylori are known to produce an extracellular cytotoxin that causes vacuolation in various mammalian cells $[1,2]$. Recently, a protein isolated from $H$. pylori culture supernates has been shown to cause vacuolation in vivo [3]. This activity of $H$. pylori may play a major role in the development of gastritis and peptic ulcer disease [4]. The gene encoding this protein (vacA) $[2,3,5]$ and the cytotoxin-associated protein ( $\operatorname{cagA})[6,7]$ have been cloned and sequenced, although the involvement of cagA in vacuolation is still under discussion $[8,9]$. Vacuole formation induced by $H$. pylori supernates is activated via an autophagic mechanism $[10,11]$. HeLa cells are often used for examining vacuolating cytotoxin activity, but may not be sensitive enough to detect minimal changes.

In this study, a more sensitive cell line was developed to examine the vacuolating cytotoxin activity of H. pylori, and quantify cell death of the cultured cells induced by clinical isolates of $H$. pylori.

Received 8 July 1996; revised version accepted 20 Dec. 1996.

Corresponding author: Professor K. Kimura.

\section{Materials and methods \\ Cells}

The following cell lines were used: HeLa (derived from human cervical carcinoma), HuL-1 (derived from normal fetal human liver), $\mathrm{M}$ (derived from normal rat liver), MK (derived from cynomolgus monkey kidney) and LYM-1 (derived from rat lymph nodes).

Measurement of vacuole formation and cell death of cultured cells

For cell culture, 24-well microtitration plates were used. The cells were cultured together with various concentrations of ammonium chloride or the H. pylori culture supernates. Cells were incubated for 5 days at $37^{\circ} \mathrm{C}$ in air with $\mathrm{CO}_{2} 5 \%$. The cultured cells were then fixed with methanol, Giemsa stained, and were observed histologically.

The extent of cell death was classified into two groups in the screening cell line, with ammonium chloride, (-, $100 \%$ alive; + , presence of cell death) and into four groups when examining $H$. pylori culture supernates $(-, 100 \%$ alive;,$+ 25 \%$ dead; $2+, 26-49 \%$ dead; $3+,>50 \%$ dead).

The severity of vacuole formation was classified into 
two groups. $(-$, no vacuole formation; and + , vacuole formation present).

\section{Tissue culture and reagents}

The growth medium was DM-201 supplemented with heat inactivated fetal bovine serum (Gibco, NY, USA) $2 \%$. Ammonium chloride (WAKO, Osaka, Japan) was used to induce vacuole formation. Various solutions of ammonium chloride were prepared after filter sterilisation of a stock solution $(50 \mathrm{mg} / \mathrm{ml})$ stored for the various experiments.

\section{H. pylori culture supernates}

All H. pylori strains were isolated from gastric biopsy samples taken from patients at Jichi Medical School
Hospital. H. pylori was cultured on Brucella agar (Difco, Detroit, USA) and then transferred to Brucella Broth (Difco) containing heat inactivated horse serum (JRH, Tokyo, Japan) and incubated at $37^{\circ} \mathrm{C}$ for up to 3 days in a micro-aerobic atmosphere. The H. pylori culture supernates were collected by centrifugation and sterilised by filtration $(0.22 \mu \mathrm{m}$ pores $)$. The supernate of a vac $A$ gene-positive strain of $H$. pylori was selected for vacuolation experiments and was used at final concentrations of 1 in 4,8,16 and 32. DM-201 medium was used for making dilutions of the supernates.

\section{$D N A$ preparation and $P C R$ detection the vacA gene}

After culture in Brucella broth, H. pylori cells were collected by centrifugation. The pellet was suspended
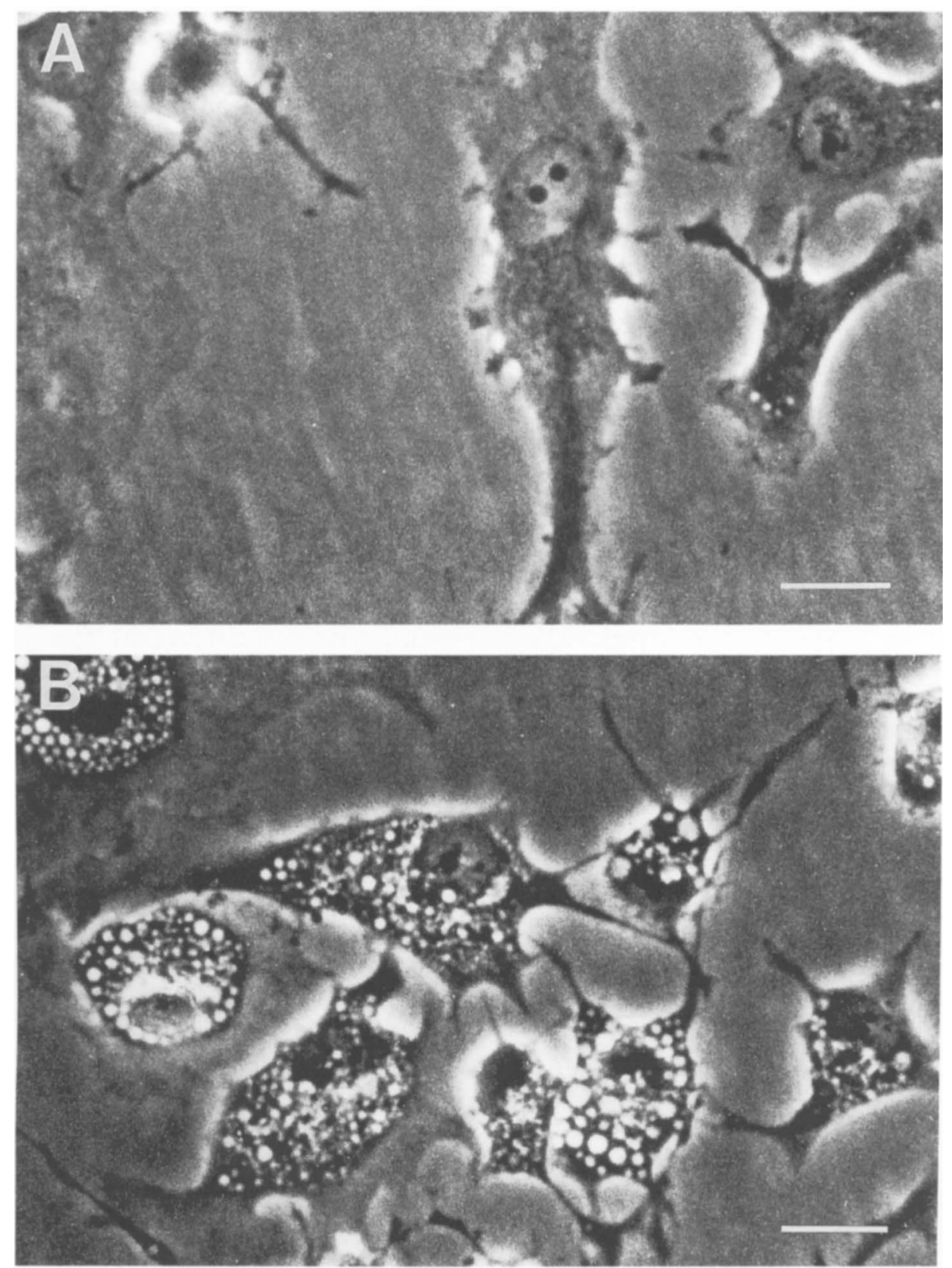

Fig. 1. Ammonium chloride-induced vacuole formation in LYM-1 cells. A, control; B, $3 \mathrm{~h}$ after addition of ammonium chloride $500 \mu \mathrm{g} / \mathrm{ml}$. Bars, $20 \mu \mathrm{m}$. 
in TE buffer ( $\mathrm{pH} \mathrm{8.0)}$ and digested with proteinase $\mathrm{K}$ (Gibco) and sodium dodecyl sulphate (SDS) $0.5 \%$ for $1 \mathrm{~h}$ at $37^{\circ} \mathrm{C}$. The solution was then treated with $\mathrm{NaCl}$. DNA was purified by phenol, phenol-chloroform extraction and ethanol precipitation, and resuspended in $100 \mu \mathrm{l}$ of double distilled $\mathrm{H}_{2} \mathrm{O} ; 10 \mu \mathrm{l}$ of DNA samples were used for PCR. The primers for amplification of the vacA gene were synthesised according to the method of Telford et al. [3]. The primers used had the following sequences: 5'-CCGAAGAAGCCAATAAAACCCCAG-3' and 5'-CAAAGTCAAAACCGTAGAGCTGGC-3'. The amplification cycle consisted of an initial denaturation at $94^{\circ} \mathrm{C}$ for $1 \mathrm{~min}$, primer annealing at $55^{\circ} \mathrm{C}$ for $2 \mathrm{~min}$ and extension at $72^{\circ} \mathrm{C}$ for $1 \mathrm{~min}$. The final cycle included an extension of the product. Samples were amplified through 20 consecutive cycles with Vent DNA polymerase (New England Biolabs, Inc., MA, USA). Samples $(10 \mu \mathrm{l})$ of the PCR products were analysed by electrophoresis in agarose $1.4 \%$ gels (Funakoshi Co. Ltd., Tokyo, Japan) containing ethidium bromide $1 \mathrm{ml} / \mathrm{L}$.

\section{Results}

Sensitivity of the cultured cells for the detection of vacuole formation induced by ammonium chloride

Five-day-old cell cultures were examined microscopically to measure the sensitivity of five cell lines for the detection of vacuole formation by ammonium chloride. Vacuole formation was observed only in LYM-1 cells with $\mathrm{NH}_{4} \mathrm{Cl} 500 \mu \mathrm{g} / \mathrm{ml}$ (Fig. 1).

\section{Vacuole formation induced by $H$. pylori culture} supernates

Vacuole formation induced by $H$. pylori culture supernates with HeLa cells and LYM-1 cells was compared. When culture supernates of 10 strains of $H$. pylori shown to be positive for the vacA gene by PCR were tested at a final dilution of 1 in 4 , vacuole formation in HeLa cells was induced by $20 \%$ of the $H$. pylori culture supernates. On the other hand, vacuole formation in LYM-1 cells was induced by all 10 supernates. In terms of vacuole formation, each $H$. pylori culture supernate showed different degrees of activity with these cells. The supernates could be classified into two groups (Table 1) where: (1) vacuole formation was found even at a dilution of 1 in 16 ; (2) vacuole formation was found only at a concentration of 1 in 4 .

\section{Cell death induced by $H$. pylori culture supernates}

Cell death occurred in each cell line but to a much lesser extent in HeLa cells, and no clear differences
Table 1. Vacuole formation and loss of viability of HeLa cells and LYM-1 cells at various concentrations of H. pylori culture supernates

\begin{tabular}{|c|c|c|c|c|c|}
\hline \multirow[b]{2}{*}{$\begin{array}{l}\text { Isolate } \\
\text { No. }\end{array}$} & \multirow[b]{2}{*}{$\begin{array}{l}\text { Dilution } \\
\text { of } \\
\text { supernates }\end{array}$} & \multicolumn{2}{|r|}{$\mathrm{HeLa}$} & \multicolumn{2}{|c|}{ LYM-1 } \\
\hline & & $\begin{array}{l}\text { Loss of } \\
\text { viability* }\end{array}$ & Vacuolation $\dagger$ & $\begin{array}{l}\text { Loss of } \\
\text { viability* }\end{array}$ & Vacuolationt \\
\hline \multirow[t]{4}{*}{1} & 1 in 4 & + & - & $3+$ & + \\
\hline & 1 in 8 & + & - & $3+$ & + \\
\hline & 1 in 16 & - & - & + & - \\
\hline & 1 in 32 & - & - & + & - \\
\hline \multirow[t]{4}{*}{2} & 1 in 4 & $2+$ & - & $3+$ & + \\
\hline & 1 in 8 & + & - & $2+$ & + \\
\hline & 1 in 16 & + & - & + & - \\
\hline & 1 in 32 & - & - & + & - \\
\hline \multirow[t]{4}{*}{3} & 1 in 4 & + & - & $3+$ & + \\
\hline & 1 in 8 & + & - & $2+$ & + \\
\hline & 1 in 16 & + & - & + & - \\
\hline & 1 in 32 & - & - & + & - \\
\hline \multirow[t]{4}{*}{4} & 1 in 4 & + & - & $3+$ & + \\
\hline & 1 in 8 & + & - & $2+$ & + \\
\hline & 1 in 16 & + & - & + & - \\
\hline & 1 in 32 & + & - & + & - \\
\hline \multirow[t]{4}{*}{5} & 1 in 4 & + & + & $2+$ & + \\
\hline & 1 in 8 & + & - & + & - \\
\hline & 1 in 16 & - & - & - & - \\
\hline & 1 in 32 & - & - & - & - \\
\hline \multirow[t]{4}{*}{6} & 1 in 4 & + & - & - & + \\
\hline & 1 in 8 & + & - & - & - \\
\hline & 1 in 16 & - & - & - & - \\
\hline & 1 in 32 & - & - & - & - \\
\hline \multirow[t]{4}{*}{7} & 1 in 4 & + & - & - & + \\
\hline & 1 in 8 & + & - & - & - \\
\hline & 1 in 16 & + & - & - & - \\
\hline & 1 in 32 & - & - & - & - \\
\hline \multirow[t]{4}{*}{8} & 1 in 4 & + & - & $3+$ & + \\
\hline & 1 in 8 & + & - & $3+$ & + \\
\hline & 1 in 16 & + & - & $3+$ & + \\
\hline & 1 in 32 & + & - & $3+$ & + \\
\hline \multirow[t]{4}{*}{9} & 1 in 4 & + & - & + & + \\
\hline & 1 in 8 & - & - & - & - \\
\hline & 1 in 16 & - & - & - & - \\
\hline & 1 in 32 & - & - & - & - \\
\hline \multirow[t]{4}{*}{10} & 1 in 4 & $2+$ & + & $3+$ & + \\
\hline & 1 in 8 & + & - & $3+$ & + \\
\hline & 1 in 16 & - & - & $3+$ & + \\
\hline & 1 in 32 & - & - & $3+$ & + \\
\hline
\end{tabular}

${ }^{*}-, 100 \%$ alive;,$+ 25 \%$ dead; $2+, 26-50 \%$ dead; $3+,>50 \%$ dead.

$\dagger-$, absence of vacuole formation; + , presence of vacuole formation.

were found among the $10 \mathrm{H}$. pylori culture supernates. On the other hand, the degree of cell death in LYM-1 cells differed among the culture supernates of $H$. pylori. Regarding cell death of the LYM-1 cells, the supernates could be classified into three groups (Table 1) where: (1) no cell death was found even by the addition of supernate at 1 in 4 dilution; (2) some cell death was found depending on the concentration of the supernates; and (3) extensive cell death was found even at a 1 in 16 dilution.

For two strains (nos. 6 and 7), the results of cell death were discordant with those for vacuole formation (vacuole formation without cell death) (Fig. 2). 

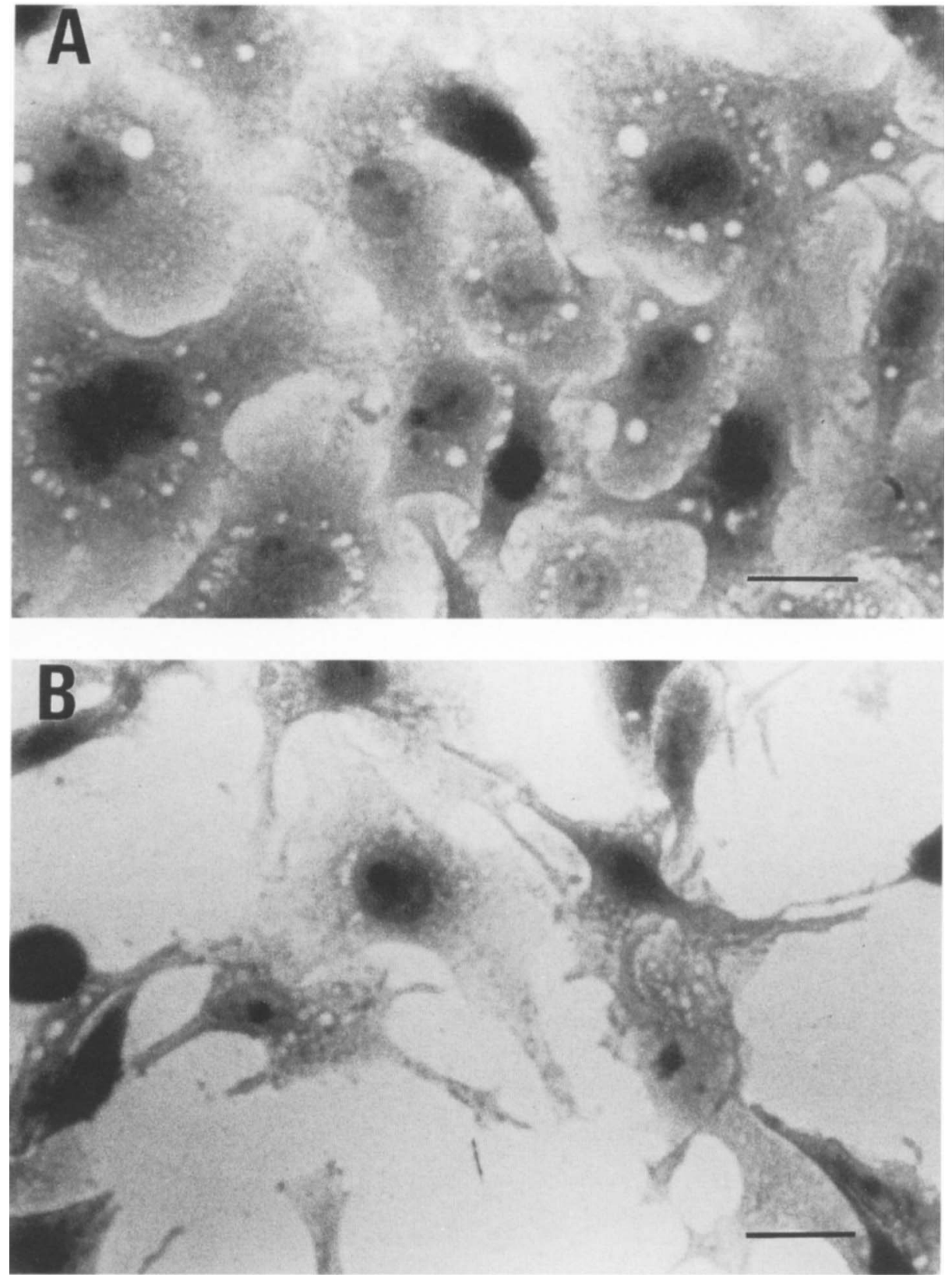

Fig. 2. Effect of $H$. pylori culture supernates on cell death and vacuole formation in LYM-1 cells at a final dilution of 1 in 4 of $H$. pylori culture supernates. A, no cell death, vacuole formation present; B, cell death, little vacuole formation. Bars, $20 \mu \mathrm{m}$.

\section{Discussion}

Toxigenic strains of $H$. pylori cause progressive vacuolation in mammalian cells, such as HeLa cells $[1,2,13]$. It has been speculated that the phenomenon of vacuole formation is associated with the gastric pathologies, such as gastric ulcer and gastritis induced by $H$. pylori infection. $H$. pylori produces ammonia by a potent urease enzyme and thus increases the $\mathrm{pH}$ of the surrounding mucus, facilitating colonisation by $H$. pylori. Ammonia produced by the urease of $H$. pylori [14] induces damage to the gastric mucosa. Moreover, vacuolating activity may be potentiated by urease-mediated ammonia production [15].
Leunk et al. [13] reported that, in vitro, broth culture filtrates of $H$. pylori induced cytopathic effects in seven of nine mammalian cell lines. Of the cells tested, Int 407 and HeLa cells were the most responsive. However, HeLa cells are not sufficiently sensitive to detect minimal differences in vacuole formation amongst different $H$. pylori culture supernates. Therefore, this study tried to identify a more sensitive cell line.

Four cell lines established in our laboratory were tested as well as HeLa cells, and it was found that LYM-1 cells were the most sensitive to damage by ammonium chloride. LYM-1 cells seemed to 
be suitable for the screening of vacuole-inducing $H$. pylori. The responses of HeLa cells and LYM-1 cells were compared by means of culture supernates from 10 strains of $H$. pylori in which the vacA gene had been identified by PCR. At a final dilution of 1 in $4, H$. pylori culture supernates, only $20 \%$ of HeLa cells displayed vacuole formation and $100 \%$ in LYM-1 cells. Although there were exceptions, when cell culture was prolonged for up to 5 days, LYM-1 cells showed clear evidence of vacuolation (strain nos. 8 and 10 in Table 1), even when the culture supernates were diluted to 1 in 16 . For detection of cytotoxic activity in HeLa cells, the filtrates had to be concentrated before assay [13]; but in LYM-1 cells, concentration of the culture supernates was not required. This is a simple and effective method for the screening and characterisation of clinical isolates of $H$. pylori. The use of LYM- 1 cells permitted the detection of minimal vacuolation activity.

When screening $H$. pylori culture supernates, two phenomena were observed - vacuolation, and loss of cell viability. With regard to vacuole formation, the $H$. pylori culture supernates showed different properties in LYM-1 cells. There are significant differences in vacA sequences between toxin-positive and toxin-negative $H$. pylori, and the mutations of the vacA gene result in the absence of cytotoxin production. In the cytotoxin-negative/vacApositive strains, there are variations in the length of the vacA gene $[2,3,5]$. The detailed mechanism of the regulation of the vacA gene remains obscure. We suppose that the amount of cytotoxin produced may be influenced by phenotypic differences in $H$. pylori strains or the occurrence of a mutation in the vacA gene. The degree of cell death in LYM-1 cells varied amongst the different $H$. pylori supernates. Vacuole formation was not necessarily correlated with cell death in LYM-1 cells. This result suggests that the factor responsible for vacuole formation may be different from that for cell death.

\section{References}

1. Cover TL, Dooley CP, Blaser MJ. Characterization of and human serologic response to proteins in Helicobacter pylori broth culture supernatants with vacuolizing cytotoxin activity. Infect Immun 1990; 58: 603-610.

2. Phadnis SH, Ilver D, Janzon L, Normark S, Westblom TU. Pathological significance and molecular characterization of the vacuolating toxin gene of Helicobacter pylori. Infect Immun 1994; 62: 1557-1565.

3. Telford JL, Ghiara P, Dell Orco M et al. Gene structure of the Helicobacter pylori cytotoxin and evidence of its key role in gastric disease. J Exp Med 1994; 179: 1653-1658.

4. Cover TL, Cao P, Lind CD, Tham KT, Blaser MJ. Correlation between vacuolating cytotoxin production by Helicobacter pylori isolates in vitro and in vivo. Infect Immun 1993; 61: 5008-5012.

5. Cover TL, Tummuru MKR, Cao P, Thompson SA, Blaser MJ. Divergence of genetic sequences for the vacuolating cytotoxin among Helicobacter pylori strains. J Biol Chem 1994; 269: 10566-10573.

6. Covacci A, Censini S, Bugnoli M et al. Molecular characterization of the $128-\mathrm{kDa}$ immunodominant antigen of Helicobacter pylori associated with cytotoxicity and duodenal ulcer. Proc Natl Acad Sci USA 1993; 90: 5791-5795.

7. Tummuru MKR, Cover TL, Blaser MJ. Cloning and expression of a high-molecular mass major antigen of Helicobacter pylori: evidence of linkage to cytotoxin production. Infect Immun 1993; 61: $1799-1809$

8. Xiang Z, Censini S, Bayeli PF et al. Analysis of expression of CagA and VacA virulence factors in 43 strains of Helicobacter pylori reveals that clinical isolates can be divided into two major types and that CagA is not neccessary for expression of the vacuolating cytotoxin. Infect Immun 1995; 63: 94-98.

9. Tummuru MKR, Cover TL, Blaser MJ. Mutation of the cytotoxin-associated CagA gene does not affect the vacuolating cytotoxin activity of Helicobacter pylori. Infect Immun 1994; 62: $2609-2613$.

10. Cover TL, Halter SA, Blaser MJ. Characterization of HeLa cell vacuoles induced by Helicobacter pylori broth culture supernatant. Human Pathol 1992; 23: 1004-1010.

11. Catrenich CE, Chestnut MH. Character and origin of vacuoles induced in mammalian cells by the cytotoxin of Helicobacter pylori. J Med Microbiol 1992; 37: 389-395.

12. Kurayama H, Ogata S, Nanba M, Ideguchi S, Takaoka T, Shida $\mathrm{S}$. Establishment of a new cell line secreting colony stimulating factor and growth inhibiting factor from metastatic lymph nodes of a rat. Dokkyo J Med Sci 1986; 13: 9-13.

13. Leunk RD, Johnson PT, David BC, Kraft WG, Morgan DR. Cytotoxic activity in broth-culture filtrates of Campylobacter pylori. J Med Microbiol 1988; 26: 93-99.

14. Konishi H, Ishibashi M, Morshed MG, Nakazawa T. Cytopathic effects of Helicobacter pylori on cultured mammalian cells. $J$ Med Microbiol 1992; 37: 118-122.

15. Cover TL, Puryear W, Perez-Perez GI, Blaser MJ. Effect of urease on HeLa cell vacuolation induced by Helicobacter pylori cytotoxin. Infect Immun 1991; 59: 1264-1270. 